\title{
PENGARUH BUDAYA ORGANISASI, HUBUNGAN KERJA, LINGKUNGAN KERJA, KEPEMIMPINAN DAN KOMPENSASI TERHADAP KEPUASAN KERJA
}

\author{
Thyophoida WSP \\ Program Studi Manajemen \\ Fakultas Ekonomi Universitas Katolik Darma Cendika \\ Jalan Dr. Ir. H. Soekarno 201, Surabaya
}

\begin{abstract}
This study examines the influence of organizational culture, labor relations, work environment, leadership and compensation to employees satisfaction John Gabriel Foundation at Kornit, Rembang. The hypothesis in this study are the organizational culture influence on employee job satisfaction, labor relations influence on employee job satisfaction, work environment influence on employee job satisfaction, leadership influence on employee job satisfaction and compensation effect on employee job satisfaction John Gabriel in Kornit, Rembang. Based on the analysis of data it can be seen that the organizational culture, labor relations, work environment and leadership had no significant effect on employee job satisfaction. While compensation significant effect on employee job satisfaction.
\end{abstract}

\begin{abstract}
ABSTRAK
Penelitian ini meneliti tentang pengaruh budaya organisasi, hubungan kerja, lingkungan kerja, kepemimpinan dan kompensasi terhadap kepuasan kerja karyawan Yayasan Yohanes Gabriel pada Kornit Rembang. Hipotesis dalam penelitian ini adalah budaya organisasi berpengaruh terhadap kepuasan kerja karyawan, hubungan kerja berpengaruh terhadap kepuasan kerja karyawan, lingkungan kerja berpengaruh terhadap kepuasan kerja karyawan, kepemimpinan berpengaruh terhadap kepuasan kerja karyawan serta kompensasi berpengaruh terhadap kepuasan kerja karyawan Yohanes Gabriel di Rembang. Berdasarkan hasil analisis data dapat diketahui bahwa budaya organisasi, hubungan kerja, lingkungan kerja dan kepemimpinan tidak berpengaruh signifikan terhadap kepuasan kerja karyawan. Sedangkan kompensasi berpengaruh signifikan terhadap kepuasan kerja karyawan.
\end{abstract}

Keywords: organizational culture, labor relations, work environment, leadership, compenasation, job satisfaction. 


\section{PENDAHULUAN}

Dunia pendidikan merupakan salah satu usaha yang bergerak di bidang jasa, di mana dewasa ini tingkat persaingan yang ada sangat ketat. Oleh karena itu sangat diperlukan sistem pengelolaan manajemen yang efisien dan efektif, hal itu berarti harus dapat dengan mudah berubah serta menyesuaikan diri san dapat mengakomodasikan setiap perubahan, yang sedang terjadi maupun yang akan datang secara cepat dan terarah (Brahmasari dan Suprayitno, 2008)

Mengelola kepuasan kerja karyawan bukanlah pekerjaan yang mudah, karena pihak pimpinan harus memperhatikan antara lain faktor-faktor yang akan mempengaruhi kepuasan kerja karyawannya, antara lain budaya organisasi, hubungan kerja, lingkungan kerja, kepemimpinan dan kompensasi.

Oleh karena itu, Yayasan Yohanes Gabriel harus memperhatkan faktor-faktor tersebut sehingga nantinya diharapkan segenap karyawan yang ada pada Kornit Rembang akan puas dan ini akan berdampak pada kinerja yang diberikan dalam melaksanakan pekerjaan.

Dalam beberapa tahun terakhir ini trend jumlah penerimaan siswa di semua sekolah yang berada di bawah Yayasan Yohanes Gabriel mengalami penurunan dari tahun ke tahun. Melihat fenomena yang ada, maka dilakukan penelitian untuk melihat penyebab terjadinya hal tersebut dari segi internal yaitu para karyawan. Harapannya dengan ditingkatkannya kepuasan kerja karyawan akan kembali meningkatkan jumlah penerimaan siswanya dari tahun ke tahun.
Memperhatikan uraian di atas, maka peneliti di sini dapat merumuskan permasalahannya sebagai berikut:

Apakah budaya organisasi, hubungan kerja, lingkungan kerja, kepemimpinan dan kompensasi berpengaruh terhadap kepuasan kerja karyawan Yayasan Yohanes Gabriel di Rembang?

\section{LANDASAN TEORI}

\section{Budaya Organisai}

Budaya organisasi adalah sistem yang dipercayai dan nilai yang dikembangkan oleh organisasi di mana hal itu menuntut perilaku dari anggota organisasi itu sendiri (Hendrianti, 2013).

Menurut Marcoulides dan Heck dalam Brahmasari dan Suprayitno (2008) budaya organisasi sebagai suatu konsep dapat menjadi suatu sarana untuk mengukur kesesuaian dari tujuan organisasi strategi dan organisasi tugas, serta dampak yang dihasilkannya.

Menurut Santo dalam Nawawi (2013: 4) budaya organisasi/perusahaan adalah nilai-nilai yang menjadi pegangan sumber daya manusia dalam menjalankan kewajiban dan perilakunya di dalam organisasi.

Dalam studi budaya organisasi (Nawawi, 2013: 6) ada 2 hal menarik, yaitu:

1. Kuat atau nyatanya budaya suatu organisasi berkaitan dengan keberhasilan atau kegagalan perusahaan/ organisasi tersebut.

2. Ideologi, simbol, dan keyakinan bersama memiliki dampak besar terhadap perusahaan, lepas dari karakteristik objektif dan strukturnya. 
Menurut Robbins dalam (Nawawi, 2013: 6) ada 7 karakteristik prima budaya organisasi, yaitu:

1. Inovasi dan keberanian mengambil resiko.

2. Perhatian terhadap detail; sejauhmana karyawan diharapkan memperlihatkan posisi kecermatan, analisis, dan perhatian pada perincian.

3. Berorientasi pada hasil; sejauhmana manajemen memfokus pada hasil, bukan pada teknis dan proses dalam mencapai hasil.

4. Berorientasi kepada manusia; sejauhmana keputusan manajemen memperhitungkan efek hasil pada orang-orang dalam organisasi.

5. Berorientasi tim; sejauhmana kegiatan kerja diorganisasikan sekitar timtim bukan individu.

6. Agresif; sejauhmana orang-orang agresif dan kompetitif.

7. Stabil; sejauhmana keinginan organisasi menekankan diterapkannya status quo sebagai kontras dari pertumbuhan.

Budaya dalam sutu organisasi sangat dinamis, hal ini dikarenakan harus disesuaikan dengan tuntutan lingkungan. Menurut Nidraha dalam Nawawi (2013: 135) yang dimaksud dengan tantangan budaya adalah tantangan yang bakal atau akan dihadapi oleh pelaku budaya atau suatu lingkungan budaya tatkala berkomunikasi atau berinteraksi dengan pelaku budaya atau lingkungan budaya lain.

Budaya organisasi dalam praktik mempunyai beberapa jenis dan tipe. Menurut Robert E. Quinn dan Michael dalam Nawawi (2010: 370) jenis budaya organisasi berdasarkan informasi yaitu:
1. Budaya Rasional.

Dalam budaya ini proses informasi individual diasumsikan sebagai sarana bagi tujuan kinerja yang ditunjukan (efisien, produktivita dan keuntungan atau dampak).

2. Budaya Ideologi

Dalam budaya ini pemprosesan informasi intuitif (dari pengetahuan yang dalam, pendapat dan inovasi) diasumsikan sebagai sarana tujuan revitalisasi (dukungan dari luar, dukungan sumber daya dan pertumbuhan).

3. Budaya Konsensus

Dalam budaya ini pemrosesan informasi kolektif (diskusi, partisipasi, konsensus) diasumsikan sebagai sarana tujuan kohesi (iklim, moral, dan kerjsama kelompok).

4. Budaya Hirarkis

Dalam budaya ini pemprosesan informasi formal (dokumen, komputasi, dan evaluasi) diasumsikan sebagai sarana bagi tujuan kesinambungan (stabilitas, kontrol, dan koordinasi).

\section{Hubungan Kerja}

Menurut Gorda dalam Matalia (2012) hubungan kerja yang menyenangkan akan mampu memperbaiki semangat dan kesungguhan kerja pegawai yang akan mempengaruhi kepuasan kerja pegawai.

Menurut Widodo dan Judiantoro (2013) hubungan kerja adalah kegiatankegiatan pengerahan tenaga/jasa seseorang secara teratur demi kepentingan orang lain yang memerintahnya (pengusaha/majikan) sesuai dengan perjanjian kerja. 
Aloewir (2013) mengemukakan bahwa pengertian hubungan kerja adalah hubungan yang terjalin antara pengusaha dan pekerja yang timbul dari perjanjian yang diadakan untuk jangka waktu tertentu maupun tidak tertentu.

Menurut Laniwidyanti et al. (2010) bentuk-bentuk hubungan kerja, adalah sebagai berikut:

1. Hubungan Manusiawi (Human Relations).

Manusia sebagai makhluk sosial akan selalu mengadakan hubungan dengan manusia lainnya. Hubungan antar manusia merupakan terjemahan dari human relations yang tertuju kepada kebahagiaan berdasarkan watak, sifat, perangai, kepribadian, sikap, tingkah laku dan lain-lain aspek kejiwaan yang terdapat pada diri manusia.

2. Hubungan seorang Atasan (Pimpinan) dengan Bawahan.

Persekutuan pada dua orang atau lebih yang bekerjasama secara formal akan terikat aturan/kebijakan guna pencapaian tujuan yang telah ditentukan dan terdapat seorang atasan dan seorang atau sekelompok orang yang disebut bawahan. Bentuk hubungan pimpinan kepada bawahan adalah: (a) Iklim saling percaya mempercayai; (b) Penghargaan terhadap ide bawahan; (c) Memperhitungkan perasaan para bawahan; (d) Perhatian pada kenyamanan kerja bagi para karyawan; (e) Perhatian pada kesejahteraan bawahan; (f) Pengakuan atas status para bawahan secara tepat dan proporsonal; (g) Memperhitungkan faktor kepuasan kerja para bawahan dalam menye- lesaikan tugas-tugas yang dipercayakan kepadanya.

3. Hubungan Teman-Sekerja.

Individu-individu tidak dapat bekerja sendirian tetapi selalu berada dalam suatu kelompok. Suatu kerjasama akan tercipta apabila masing-masing dapat memahami tingkah laku orang lain. Oleh karena itu, hubungan teman sekerja yang merupakan lingkungan kerja terdekat sangat mempe-ngaruhi situasi kerja dan juga akan mempengaruhi dalam pencapaian tujuan organisasi.

\section{.Lingkungan kerja}

Menrut Tohari dalam Hendrianti (2013), lingkungan kerja fisik walaupun diyakini bukan faktor utama dalam meningkatkan produktivitas karyawan, namun faktor lingkungan kerja fisik merupakan variabel yang perlu diperhitungkan oleh para pakar manajemen dalam pengaruhnya untuk meningkatkan produktivitas.

Theodore dalam Sofyan (2013) faktor-faktor yang mempengaruhi lingkungan kerja sebagai berikut:

1. Fasilitas Kerja.

Lingkungan kerja yang dirasa tidak mendukung pelaksanaan kerja akan menyebabkan kinerja yang jelek, seperti kurangnya peralatan pendukung kerja, ruang kerja yang pengap, ventilasi yang kurang serta tidak ada prosedur yang jelas.

2. Gaji dan Tunjangan.

Gaji yang tidak sesuai dengan harapan akan menyebabkan terjadinya perpindahan karyawan ke perusahaan lain. 
3. Hubungan Kerja.

Kelompok kerja yang kompak dan memiliki loyalitas yang tinggi akan meningkatkan produktivitas kerja.

\section{Kepemimpinan}

Kepemimpinan adalah kemampuan meyakinkan dan menggerakkan orang lain agar mau bekerjasama dibawah kepemimpinannya sebagai suatu tim untuk mencapai suatu tujuan tertentu (Samsudin, 2006: 287).

DuBrin dalam Brahmasari dan Suprayitno (2008: 126) mengemukakan bahwa kepemimpinan adalah upaya mempengaruhi banyak orang melalui komunikasi untuk mencapai tujuan, cara mempengaruhi orang dengan petunjuk atau perintah, tindakan yang menyebabkan orang lain bertindak atau merespons dan menimbulkan perubahan positif, kekuatan dinamis penting yang memotivasi dan mengkoordinasikan organisasi dalam rangka mencapai tujuan, kemampuan untuk menciptakan rasa percaya diri dan dukungan diantara bawahan agar tujuan organisasional dapat tercapai.

Sebagaimana kita ketahui bahwa kepemimpinan adalah suatu proses yang dilakukan seseorang dalam mengarahkan dan mempengaruhi orang lain guna melaksanakan tugasnya sehingga tujuan suatu organisasi akan tercapai. Ada 4 (empat) unsur dalam kepemimpinan (Bangun, 2012: 340) yaitu:

1. Kumpulan orang.

Dalam suatu organisasi terdapat sekelompok pengikut untuk mencapai tujuan organisasi. Di mana tanpa adanya kelompok maka suatu kepemimpinan tidak akan terwujud.
2. Kekuasaan.

Kekuasan merupakan kekuatan yang dimiliki seoang pemimpin untuk mempengaruhi para pengikutnya dalam melaksankan tugasnya.

Ada 5 dasar kekuasaan yang dimiliki oleh pemimpin,antara lain:

a. Kekuasaaan menghargai.

b. Kekuasaan memaksa.

c. Kekuasaan sah.

d. Kekuasaan rujukan.

e. Kekuasaaan keahlian.

3. Memengaruhi.

Seorang pemimpin harus mampu menggunakan semua bentuk kekuasaan yang dimiliki guna mempengaruhi anggota organisasi supaya mau melaksanakan tugasnya.

4. Nilai.

Pemimpin yang mengabaikan komponen moral dalam kepemimpinannya mungkin akan dikenang sebagai penjahat.

\section{Kompensasi}

Pengaturan pemberian kompensasi merupakan faktor yang sangat penting bagi perusahaan dalam usaha menarik, memelihara maupun mempertahankan karyawannya bagi kepentingan perusahaan/organisasi, di mana kompensasi merupakan suatu balas jasa yang diterima karyawan sebagai balas jasa atas apa yang sudah mereka kerjakan.

Menurut Flippo dalam Samsudi (2006: 187) kompensasi adalah harga untuk jasa yang diterima atau diberikan oleh orang lain bagi kepentingan seseorang atau badan hukum. Sedangkan menurut Dessler dalam Samsudi (2006: 187) kompensasi adalah setiap bentuk pembayaran atau imbalan yang diberikan kepada karyawan dan timbul dari 
dipekerjakannya karyawan. Menurut Samsudin (2006: 187) kompensasi mempunyai 2 aspek, yaitu:

1. Pembayaran keuangan langsung dalam bentuk upah, gaji, insentif, komisi, dan bonus.

2. Pembayaran tidak langsung, dalam bentuk tunjangan keuangan, seperti asuransi dan uang liburan yang diberikan.

Adapaun fungsi dan tujuan dari pemberian kompensasi (Ardana et al., 2012: 154), yaitu:

1. Ikatan kerjasama; dengan pemberian kompensasi maka akan terjalin ikatan kerjasama formal antara majikan dan karyawan, dimana karyawan harus mengerjakan tugastugas dengan baik sedang pengusaha wajib membayar kompensasi sesuai dengan perjanjian.

2. Kepuasan kerja; dengan balas jasa diharapkan karyawan dapat memenuhi kebutuhan fisik, sosial dan egoistiknya sehingga karyawan memperoleh kepuasan kerja.

3. Pengadaan efektif; bila program kompensasi ditetapkan dengan benar maka pengadaan karyawan yang qualified untuk perusahaan lebih mudah.

4. Motivasi; bila balas jasa yang diterima cukup besar, maka akan lebih mudah memotivasi karyawan.

5. Stabilitas karyawan; program kompensasi atas prinsip adil dan layak serta eksternal konsistensi yang kompetitif maka stabilitas karyawan lebih terjamin sehingga turn over relative kecil.

6. Disiplin; pemberian balas jasa yang cukup maka disiplin karyawan semakin baik.
7. Pengaruh serikat buruh; program kompensasi yang baik maka pengaruh serikat buruh dapat dihindarkan dan karyawan akan berkonsentrasi pada pekerjaannnya.

8. Pengaruh pemerintah; jika kompensasi sesuai dengan undang-undang perbutuhan yang berlaku sehingga intervensi pemerintah dapat dihindari.

Menurut Samsudin (2006: 190) perusahaan/organisasi dalam menetapkan besarnya gaji atau upah yang adil harus memperhatikan lima langkah berikut ini:

1. Lakukan survei gaji terhadap beberapa perusahaan lain mengenai besarnya upah untuk pekerjaan yang sebanding.

Hal ini bertujuan untuk dapat menetapkan tarif upah yang sesuai/ berlaku di masyarakat

2. Tentukan nilai dari masing-masing pekerjaan melalui evaluasi jabatan.

Di mana evaluasi jabatan bertujuan menetapkan nilai relatif dari suatu jabatan, di mana jabatan dibandingkan satu dengan yang lain berdasarkan kesulitan pekerjaan, tanggung jawab dan ketrampilan yang dibutuhkan.

3. Kelompok pekerjaan-pekerjaan serupa ke dalam tingkatan upah.

4. Tetapkan harga masing-masing tingkat pembayaran dengan menggunakan kurva upah. Di mana kurva upah memperlihatkan hubungan antara nilai jabatan dengan upah rata-rata untuk jabatan tertentu.

5. Tentukan tarif upah. 


\section{Kepuasan keja}

Menurut Werther dan Davis dalam Brahmasari dan Suprayitno (2008: 127) dapat dikatakan bahwa kepuasan kerja adalah kondisi kesukaan dan ketidaksukaan menurut pandangan karyawan terhadap pekerjaannya.

Sedangkan menurut Gibson et al. dalam Brahmasari dan Suprayitno (2008: 127) mengemukakan bahwa kepuasan kerja merupakan bagian dari proses motivasi. Di mana kepuasan suatu anggota organisasi dapat dihubungkan dengan kinerja dan hasil kerja serta imbalan dan hukuman yang diterima.

Robbins dalam Brahmasari dan Suprayitno (2008: 127) mengemukakan bahwa kepuasan kerja sebagai suatu sikap umum seorang individu terhadap pekerjaannya. Di mana suatu pekerjaan menuntut adanya kerjasama antara karyawan dengan rekan kerja serta dengan atasan sesuai dengan kebijakan yang ada sehingga diharapkan nantinya akan tercapai standar kinerja.

Menurut Robbins (2011: 148) beberapa faktor yang menentukan kepuasan kerja dari seorang karyawan sebagai berikut:

1. Kerja yang secara mental menantang. Karyawan menyukai pekerjaan yang memberi kesempatan kepada mereka untuk menggnakan ketrampilan dan kemampuan yang dimiliki dalam bekerja.

2. Ganjaran yang pantas. Karyawan menginginkan sistem upah dan kebijakan promosi yang mereka persepsikan sebagai adil, tidak meragukan, dan segaris dengan pengharapan mereka. Bila upah dilihat sebagai adil yang didasarkan pada tuntutan pekerjaan, tingkat keterampilan indi- vidu, dan standar pengupahan komunitas, kemungkinan besar akan dihasilkan kepuasan.

3. Kondisi kerja yang mendukung. Karyawan peduli akan lingkungan kerja, baik untuk kenyamanan pribadi maupun untuk memudahkan mengerjakan tugas yang baik.

4. Rekan kerja yang mendukung. Bagi kebanyakan karyawan, kerja untuk mengisi kebutuhan akan interaksi sosial. Sehingga mempunyai rekan kerja yang ramah dan mendukung akan menimbulkan kepuasan kerja yang meningkat.

\section{HIPOTESIS}

Hipotesis dalam penelitian ini adalah:

1. Budaya organisasi berpengaruh terhadap kepuasan kerja karyawan Yohanes Gabriel di Rembang.

2. Hubungan kerja berpengaruh terhadap kepuasan kerja karyawan Yohanes Gabriel di Rembang.

3. Lingkungan kerja berpengaruh terhadap kepuasan kerja karyawan Yohanes Gabriel di Rembang.

4. Kepemimpinan berpengaruh terhadap kepuasan kerja karyawan Yohanes Gabriel di Rembang.

5. Kompensasi berpengaruh terhadap kepuasan kerja karyawan Yohanes Gabriel di Rembang.

\section{METODE PENELITIAN}

Obyek yang diteliti dalam penelitian ini adalah budaya organisasi, hubungan kerja, lingkungan kerja, kepemimpinan, kompensasi dan kepuasan kerja karyawan Yayasan Yohanes Gabriel Kornit Rembang. Sampel penelitian adalah karyawan Yayasan Yohanes Gabriel Kornit Rembang 
sebanyak 35 responden. Untuk Prosedur pengumpulan data dalam penelitian ini, dapat dilakukan dengan cara observasi, wawancara dan menggunakan kuesioner dengan skala Likert.

Variabel dalam penelitian ini, sebagai berikut:

- Budaya organisasi (X1);

- Hubungan kerja (X2);

- Lingkungan kerja (X3);

- Kepemimpinan (X4);

- Kompensasi (X5);

- Kepuasan Kerja (Y).

\section{Teknik Analisa Data}

\section{Analisis Regresi Linier Berganda}

Teknik analisis yang digunakan dalam penelitian ini adalah Analisis regresi linier berganda. Analisa ini bertujuan untuk mengetahui seberapa besar pengaruh variabel independen (X) terhadap variabel dependen (Y). Model persamaan regresi linier berganda sebagai berikut:

$\mathrm{Y}=\mathrm{b}_{0}+\mathrm{b}_{1} \mathrm{X}_{1}+\mathrm{b}_{2} \mathrm{X}_{2}+\mathrm{b}_{3} \mathrm{X}_{3}+\mathrm{b}_{4} \mathrm{X}_{4}+$ $\mathrm{b}_{5} \mathrm{X}_{5}$

Keterangan:

$\mathrm{Y}=$ Kepuasan kerja

$\mathrm{b}_{0}=$ konstanta

$b_{1} \ldots b_{5}=$ koefisien regresi

$\mathrm{X}_{1}=$ Budaya organisasi

$\mathrm{X}_{2}=$ Hubungan kerja

$\mathrm{X}_{3}=$ Lingkungan kerja

$\mathrm{X}_{4}=$ Kepemimpinan

$\mathrm{X}_{5}=$ Kompensasi

$\mathrm{e}=$ variabel pengganggu, merupakan wakil dari semua faktor lain yang dapat mempengaruhi keputusan pembelian.

\section{Pengujian Hipotesis}

Pengujian hipotesis digunakan untuk mengetahui pengaruh variabel bebas baik secara simultan maupun secara parsial terhadap variabel terikat, serta untuk mengetahui variabel bebas yang paling dominan terhadap variabel terikat.

1. Uji F

Uji F dimaksudkan untuk menguji hipotesis apakah variabel bebas secara simultan mempunyai pengaruh terhadap variabel terikat.

2. Uji t

Uji t dimaksudkan untuk menguji hipotesis apakah variabel bebas secara parsial mempunyai pengaruh terhadap variabel terikat.

\section{HASIL PENELITIAN}

\section{Analisis Model Regresi Linier Berganda}

Berdasarkan penelitian ini, maka persamaan regresi bergandanya dapat dinyatakan sebagai berikut :

$$
\begin{aligned}
\mathrm{Y}= & 10,874-0,080 \mathrm{X}_{1}-0,320 \mathrm{X}_{2}+ \\
& 0,384 \mathrm{X}_{3}+0,185 \mathrm{X}_{4}+0,625 \mathrm{X}_{5}
\end{aligned}
$$

Berdasarkan model regresi linier berganda ini dapat dijelaskan bahwa :

a. Nilai $b_{0}$ sebesar $=10,874$.

Konstanta sebesar 10,874 menunjukkan bahwa terjadinya kepuasan kerja karyawan sebesar 10,874 satuan dengan asumsi seluruh variabel independen $\left(\mathrm{X}_{1}, \mathrm{X}_{2}, \mathrm{X}_{3}, \mathrm{X}_{4}\right.$, dan $\left.\mathrm{X}_{5}\right)$ konstan.

b. Nilai $b_{1}$ sebesar $=-0,080$.

Menunjukkan bahwa jika Budaya organisasi $\left(\mathrm{X}_{1}\right)$ meningkat sejumlah satu satuan maka, akan menurunkan kepuasan kerja karyawan sebesar 0,080 satuan dengan asumsi variabel bebas yang lain yaitu hubungan kerja, lingkungan kerja, kepemimpinan dan kompensasi konstan. 
c. $\quad$ Nilai $b_{2}$ sebesar $=-0,320$.

Menunjukkan bahwa jika hubungan kerja $\left(\mathrm{X}_{2}\right)$ meningkat sejumlah satu satuan, maka akan menurunkan kepuasan kerja sebesar 0,320. satuan dengan asumsi variabel bebas yang lain yaitu budaya organisasi, lingkungan kerja, kepemimpinan dan kompensasi konstan.

d. Nilai $b_{3}$ sebesar 0,384.

Menunjukkan bahwa jika lingkungan kerja (X3) meningkat sejumlah satu satuan, maka akan meningkat kepuasan kerja sebesar 0,384. satuan dengan asumsi variabel bebas yang lain yaitu budaya organisasi, hubungan kerja, kepemimpinan dan kompensasi konstan.

e. Nilai $b_{4}$ sebesar 0,185.

Menunjukkan bahwa jika kepemimpinan $\left(\mathrm{X}_{4}\right)$ meningkat sejumlah satu satuan, maka akan meningkat kepuasan kerja sebesar 0,185 satuan dengan asumsi variabel bebas yang lain yaitu budaya organisasi, hubungan kerja, lingkungan kerja dan kompensasi konstan.

f. Nilai $b_{5}$ sebesar 0,625

Menunjukkan bahwa jika kompensasi $\left(\mathrm{X}_{5}\right)$ meningkat sejumlah satu satuan, maka akan meningkat kepuasan kerja sebesar 0,625 satuan dengan asumsi variabel bebas yang lain yaitu budaya organisasi, hubungan kerja, lingkungan kerja, dan kepemimpinan konstan.

\section{Analisis Koefisien Determinasi Berganda ( $\left.\mathbf{R}^{2}\right)$}

Berdasarkan Tabel di bawah ini dapat dikatakan bahwa variabel bebas yakni $\mathrm{X}_{1}, \mathrm{X}_{2}, \mathrm{X}_{3}, \mathrm{X}_{4}$ dan $\mathrm{X}_{5}$, dapat menjelaskan variabel terikat yakni kepuasan kerja sebesar $\mathrm{R}$ Square (koefisien determinasi) yakni dengan tingkat kesalahan didalam memprediksi sebesar 5\% atau sumbangan $X$ terhadap Y sebesar 47,4\%. dan 52,6\% sisanya sebesar dipengaruhi oleh variabel lain. Nilai $\mathrm{R}^{2}$ adjusted sebesar 0,384.\% menunjukkan bahwa kepuasan kerja dapat dijelaskan oleh variabel bebas sebesar 0,384\% dan 61,6\% dijelaskan oleh faktor-faktor lain.

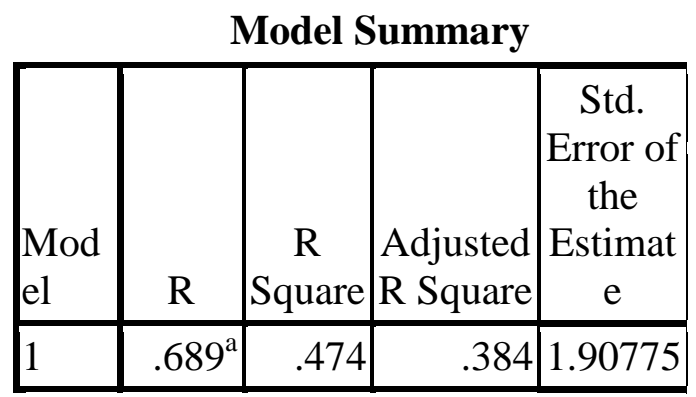

a. Predictors: (Constant), X5, X1, X4, X3, X2

Uji Pengaruh Simultan dengan Uji F Variabel budaya organisasi, hubungan kerja, lingkungan kerja, kepemimpinan dan kompensasi, secara simultan berpengaruh signifikan terhadap keputusan kepuasan kerja.

ANOVA $^{b}$

\begin{tabular}{|r|r|r|r|r|r|}
\hline Model & $\begin{array}{c}\text { Sum of } \\
\text { Squares }\end{array}$ & df & $\begin{array}{c}\text { Mean } \\
\text { Square }\end{array}$ & F & Sig. \\
\hline 1 Regr & 95.197 & 5 & 19.039 & 5.231 & $.002^{\mathrm{a}}$ \\
$\begin{array}{l}\text { essio } \\
\mathrm{n}\end{array}$ & & & & & \\
$\begin{array}{l}\text { Resi } \\
\text { dual }\end{array}$ & 105.545 & 29 & 3.639 & & \\
Total & 200.743 & 34 & & & \\
\hline
\end{tabular}

a. Predictors: (Constant), X5, X1, X4, X3, X2

b. Dependent Variable: Y 
Berdasarkan Tabel diatas dapat dilihat nilai $\mathrm{F}$ test sebesar 5, 231 lebih besar dan tingkat signifikan sebesar 0,002 yang lebih kecil dari nilai alpha yang sudah ditentukan sebesar $5 \%$, ni berarti hipotesis alternatif (Ha) yang menyatakan bahwa budaya organisasi, hubungan kerja, lingkungan kerja, kepemimpinan dan kompensasi secara simultan berpengaruh secara signifikan terhadap kepuasan kerja dapat diterima.

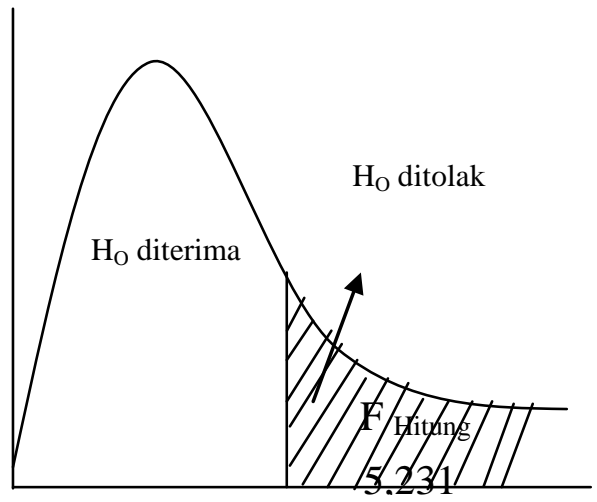

\section{UJI HIPOTESIS}

Uji Hipotesis dengan Uji t

Variabel budaya organisasi, hubungan kerja, lingkungan kerja, kepemimpinan dan kompensasi, secara parsial berpengaruh signifikan terhadap keputusan kepuasan kerja.

\begin{tabular}{|c|r|r|r|r|r|}
\hline \multirow{2}{*}{ Model } & \multicolumn{1}{c|}{ B } & \multicolumn{1}{|c|}{$\begin{array}{c}\text { Std. } \\
\text { Error }\end{array}$} & \multicolumn{1}{|c|}{$\begin{array}{c}\text { Standardi } \\
\text { zed } \\
\text { Znstandardized } \\
\text { Coefficie } \\
\text { nts }\end{array}$} & \multicolumn{1}{c|}{$\mathrm{t}$} & \multicolumn{1}{c|}{ Sig. } \\
\cline { 2 - 4 } 1 (Cons & 10.874 & 3.782 & & 2.875 & .007 \\
tant) & & & & & \\
X1 & -.080 & .195 & -.073 & -.410 & .685 \\
X2 & -.320 & .232 & -.359 & -1.379 & .178 \\
X3 & .384 & .248 & .332 & 1.552 & .131 \\
X4 & .185 & .117 & .346 & 1.581 & .125 \\
X5 & .625 & .256 & .520 & 2.443 & .021 \\
\hline
\end{tabular}

a. Dependent Variable: Y

\section{Hasil Pengujian Hipotesis}

Hipotesis 1 : Budaya organisasi tidak berpengaruh signifikan terhadap kepuasan kerja karyawan Yohanes Gabriel di Rembang.

Hipotesis 2 : Hubungan kerja tidak berpengaruh signifikan terhadap kepuasan kerja karyawan Yohanes Gabriel di Rembang.

Hipotesis 3 : Lingkungan kerja tidak berpengaruh signifikan terhadap kepuasan kerja karyawan Yohanes Gabriel di Rembang. 
Hipotesis 4 : Kepemimpinan tidak berpengaruh signifikan terhadap kepuasan kerja karyawan Yohanes Gabriel di Rembang.

Hipotesis 5 : Kompensasi berpengaruh signifikan terhadap kepuasan kerja karyawan Yohanes Gabriel di Rembang.

\section{PEMBAHASAN}

\section{Pengaruh Budaya Organisasi} terhadap Kepuasan Kerja Karyawan

Hasil penelitian ini menunjukkan bahwa variabel budaya organisasi $\left(\mathrm{X}_{1}\right)$ tidak berpengaruh signifikan terhadap kepuasan kerja karyawan, di mana dari hasil perhitungan memiliki nilai t hitung sebesar -0.410 dengan tingkat signifikan sebesar 0,685 yang lebih besar dari nilai tingkat signifikan $(\alpha)$ yang sudah ditentukan sebesar 0,05. Hal ini berarti, budaya organisasi tidak diperlukan karyawan dalam mencapai kepuasan kerja, dimana tingkat kepuasan dari setiap karyawan berbeda antara satu dengan yang lain.

\section{Pengaruh Hubungan Kerja terhadap Kepuasan Kerja Karyawan}

Hasil penelitian menunjukkan bahwa variabel hubungan kerja $\left(\mathrm{X}_{2}\right)$ tidak memiliki pengaruh signifikan terhadap kepuasan kerja karyawan, dimana memiliki nilai t hitung sebesar 1,379 dengan tingkat signifikan sebesar 0,178 yang lebih besar dari nilai tingkat signifikan $(\alpha)$ yang sudah ditentukan sebesar 0,05. Hal ini berarti, hubungan kerja tidak diperlukan karyawan dalam mencapai kepuasan kerja,.

\section{Pengaruh Lingkungan Kerja terhadap Kepuasan Kerja Karyawan}

Hasil penelitian menunjukkan bahwa variabel lingkungan kerja $\left(\mathrm{X}_{3}\right)$ tidak memiliki pengaruh signifikan terhadap kepuasan kerja karyawan, dimana memiliki nilai t hitung sebesar 1,552 dengan tingkat signifikan sebesar 0,131 yang lebih besar dari nilai tingkat signifikan $(\alpha)$ yang sudah ditentukan sebesar 0,05. Hal ini berarti, lingkungan kerja tidak diperlukan karyawan dalam mencapai kepuasan kerja,.

\section{Pengaruh Kepemimpinan terhadap Kepuasan Kerja Karyawan}

Hasil penelitian menunjukkan bahwa variabel kepemimpian $\left(\mathrm{X}_{4}\right)$ tidak memiliki pengaruh signifikan terhadap kepuasan kerja karyawan, dimana memiliki nilai t hitung sebesar 1,581 dengan tingkat signifikan sebesar 0,125 yang lebih besar dari nilai tingkat signifikan $(\alpha)$ yang sudah ditentukan sebesar 0,05. Hal ini berarti, lingkungan kerja tidak diperlukan karyawan dalam mencapai kepuasan kerja,.

\section{Pengaruh Kompensasi terhadap Kepuasan Kerja Karyawan}

Hasil penelitian menunjukkan bahwa variabel kompensasi $\left(\mathrm{X}_{5}\right)$ memiliki pengaruh signifikan terhadap kepuasan kerja karyawan, dimana memiliki nilai t hitung sebesar 2,443 dengan tingkat signifikan sebesar 0,021 yang lebih kecil dari nilai tingkat signifikan $(\alpha)$ yang sudah ditentukan sebesar 0,05. Hal ini berarti pemberian kompensasi yang ditetapkan sangat mempengaruhi kepuasan kerja karyawan yang nantinya akan berdampak bagi kinerja karyawan. 
Pengaruh Budaya Organisasi, Hubungan Kerja, Lingkungan Kerja, Kepemimpinan dan Kompensasi Terhadap Kepuasan Kerja

\section{KESIMPULAN}

Berdasarkan hasil analisis data dengan menggunakan SPSS versi 17 dan pembahasan yang telah disampaikan diatas, maka dapat diambil kesimpulan sebagai berikut:

1. Secara simultan variabel budaya organisasi, hubungan kerja, lingkungan kerja, kepemimpinan dan kompensasi berpengaruh signifikan terhadap terjadinya kepuasan kerja karyawan.

2. Variabel bebas yakni $X_{1}, X_{2}, X_{3}, X_{4}$ dan $\mathrm{X}_{5}$, dapat menjelaskan variabel terikat yakni kepuasan kerja sebesar $\mathrm{R}$ Square (koefisien determinasi) yakni dengan tingkat kesalahan didalam memprediksi sebesar 5\% atau sumbangan $\mathrm{X}$ terhadap $\mathrm{Y}$ sebesar $47,4 \%$. dan $52,6 \%$ sisanya sebesar dipengaruhi oleh variabel lain. Nilai $\mathrm{R}^{2}$ adjusted sebesar 0,384.\% menunjukkan bahwa kepuasan kerja dapat dijelaskan oleh variabel bebas sebesar 0,384\% dan $61,6 \%$ dijelaskan oleh faktorfaktor lain.

3. Budaya organisasi tidak berpengaruh signifikan terhadap kepuasan kerja karyawan.

4. Hubungan kerja tidak berpengaruh signifikan terhadap kepuasan kerja karyawan.

5. Lingkungan kerja tidak berpengaruh signifikan terhadap kepuasan kerja karyawan

6. Kepemimpinan tidak berpengaruh signifikan terhadap kepuasan kerja karyawan.

7. Kompensasi berpengaruh secara signifikan terhadap terjadinya kepuasan kerja karyawan.

\section{SARAN}

Berdasarkan hasil analisa dan pembahasan diatas maka dapat dikatakan bahwa pihak Yayasan lebih memperhatikan kompensasi yang diberikan kepada para karyawan, karena hal tersebut sangat mempengaruhi tingkat tingkat kepuasan kerja karyawan yang pada akhirnya akan berdampak pada kinerja karyawan.

\section{DAFTAR KEPUSTAKAAN}

Aloewir, 2013, http://www.sarjanaku. com/2013/03/pengertian-hubungankerja-definisi.html.

Ardana, I Komang, Ni Wayan Mujiati, I Wayan Mudiartha Utama, 2012, Manajemen Sumber Daya Manusia, Graha Ilmu, Yogyakarta.

Bangun, Wilson 2012, Manajemen Sumber Daya Manusia, Erlangga.

Brahmasari, Ida Ayu dan Agus Suprayitno, 2008, Pengaruh Motivasi Kerja, Kepemimpinan dan Budaya Organisasi Terhadap Kepuasan Kerja Karyawan serta Dampaknya pada Kinerja Perusahaan (Studi Kasus pada PT. Pei Hai International Wiratama Indonesia), Jurnal Manajemen dan Kewirausahaan, Vol. 10, No. 2, September, hal. 124-135.

Hendrianti, 2013, Pengaruh Budaya Organisasi dan Lingkungan Kerja Terhadap Motivasi Kerja Karyawan pada PT Badjatex Bandung, Skripsi Tidak Dipublikasikan, Fakultas Ekonomi, Universitas Komputer Indonesia, Bandung. 
Pengaruh Budaya Organisasi, Hubungan Kerja, Lingkungan Kerja, Kepemimpinan dan Kompensasi Terhadap Kepuasan Kerja

https://teorionline.wordpress.com/2011/ 10/23/teori-kepuasan-kerja.

Laniwidyanti, Noermijati dan Armanu Thoyib, 2010, Pengaruh Hubungan Kerja, Pengalaman Kerja dan Motivasi Kerja Terhadap Kinerja Karyawan Bank Central Asia (BCA) Cabang Borobudur, Malang, Wacana, Vol. 13 No.2.

Matalita, 2012, Pengaruh Kepemimpinan dan Hubungan Kerja Terhadap Pengembangan Karier dan Kepuasan Kerja Pegawai di Kantor Sekretariat Pemerintah Daerah Provinsi Bali, Jurnal Manajemen, Strategi Bisnis dan Kewirausahaan, Vol. 6, No. 2.

Nawawi, Ismail, 2010, Perilaku Organisasi: Teori, Transformasi Aplikasi pada Organisasi Bisnis, Politik dan Sosial, Dwiputra Pustaka Jaya, Jakarta.

, 2013, Budaya Organisasi, Kepemimpinan dan Kinerja, Kencana, Jakarta.

Purwanto, Erwan Agus dan Diyah Ratih Sulistyastuti, 2007, Metode Penelitian Kuantitatif: Untuk Administrasi Publik dan Masalah-Masalah Sosial, Gava Media, Yogyakarta.
Robbins, Stephan, 2011, Perilaku Organisasi, Edisi Kedelapan, Prenhalindo, Jakarta.

Samsudin, Saili, 2006, Manajemen Sumber Daya Manusia, Pustaka Setia, Bandung.

Sofyan, Diana Khairani, 2013, Pengaruh Lingkungan Kerja Terhadap Kinerja Kerja Pegawai Bappeda, Malikussaleh Industrial Engineering Journal, Vol. 2., No. 1.

Sugiyono, 2001, Statistika untuk Penelitian, Edisi Ketiga, Alfabeta, Bandung.

Supranto, J., 2001, Statistik dan Aplikasi, Edisi Lima, Jilid 2, Erlangga, Jakarta.

Widodo, Hartono dan Judiantoro, 2013, http://www.sarjanaku.com/2013/03/ pengertian-hubungan-kerja-definisi. html. 